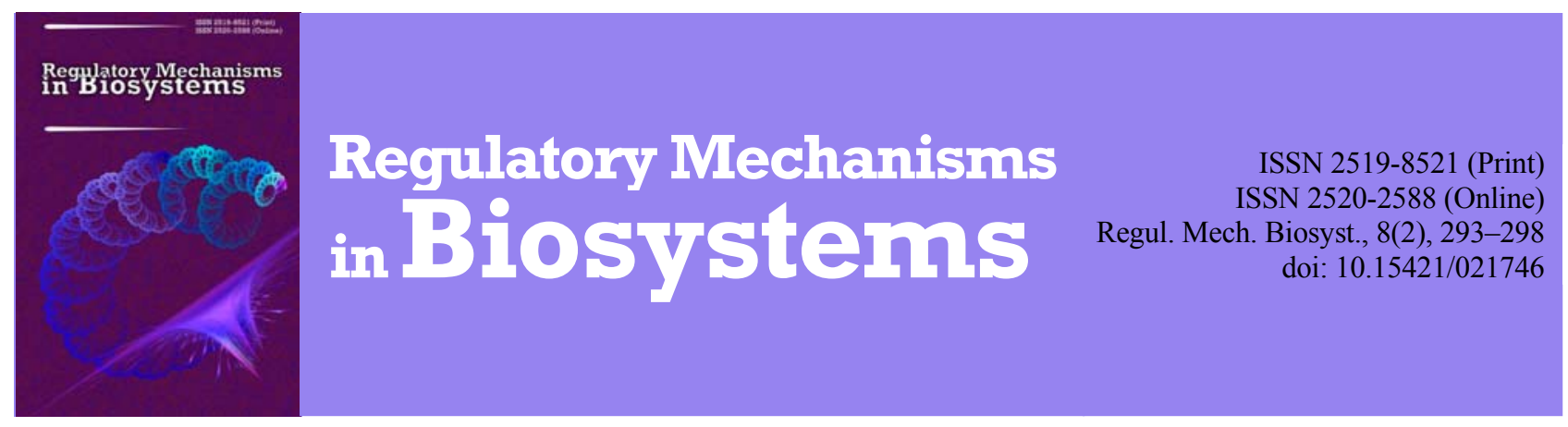

\title{
The influence of a mineral-vitamin premix on the metabolism of pregnant horses with microelemetosis
}

\author{
A. G. Shcherbatyy*, L. G. Slivinska*, B. V. Gutyj*, V. I. Golovakha**, A. V. Piddubnyak**, V. L. Fedorovuch* \\ *Lviv National University of Veterinary Medicine and Biological Technologies named after S Z Gjyzky, Lviv, Ukraine \\ **Bila Tserkva Agricultural University, Bila Tserkva, Ukraine
}

Article info

Received 29.03.2017

Received in revised form 22.04.2017

Accepted 25.04.2017

Stepan Gzhytskyi National University of Veterinary Medicine and Biotechnologies Lviv, Pekarska Str., 50, Lviv, 79010, Ukraine.

Bila Tserkva National Agricultural University, Soborna sq., 8/1,

Bila Tserkva, 09100, Ukraine. Tel.: +38-068-136-20-54

E-mail:bvh@ukr.net
Shcherbatyy, A. G., Slivinska, L. G., Gutyj, B. V., Golovakha, V. I., Piddubnyak, A. V., \& Fedorovuch, V. L. (2017). The influence of a mineral-vitamin premix on the metabolism of pregnant horses with microelemetosis. Regulatory Mechanisms in Biosystems, 8(2), 293-398. doi:10.15421/021746

The article presents data on research into the influence of a mineral-vitamin premix on the clinical condition, erythropoiesis and the metabolism (macro- and micro-elemental, vitaminic, proteinaceous, enzymic) of Hucul breed mares in the last trimester of pregnancy. The Marmix premix contains: vitamins $-A, D_{3}, E, B_{1}, B_{2}, B_{12}$, pantothenic and ascorbic acids, niacin, biotin; nonorganic compounds of microelements - sulphate of cobalt, copper, zinc, iron, manganese; potassium iodide, sodium selenite; amino acids - lysine, threonine, methionine. The usage of the mineralvitaminic premix Marmix on pregnant mares during 60 days causes recovery of clinical status, erythropoiesis, raises the level of the cobalt (by $45.9 \%$ ) and copper (by 2.15 times), normalizes the calcium-phosphorus ratio, raises the phosphorus level in the blood (by 17.7\%), raises vitamin A (by 2.5 times) and tocopherol (by 2.02 times), total protein (by $27.7 \%$ ), decreases the level of urea (by $42.2 \%$ ), activity of AspAT [aspartate transaminase or aspartate aminotransferase] (by $42.9 \%$ ) and AlAT [alanine transaminase] (by $44.9 \%$ ) and alkaline phosphatase (by $43.7 \%$ ). The research conducted contributes to improvements in the study of the pathogenesis of microelementosis of mares and develops an efficient way of treating and preventing the development of microelementosis among these animals.

\section{Introduction}

Hucul horses should no doubt be considered as one of the national treasures of Ukraine (Stefurak, 2004; Golovach et al., 2005). The Hucul horse is a true mountain breed. These animals are often used for work in forests, and also for riding and carrying loads via mountain paths, for this relatively small horse is strong, resistant to diseases and can live outdoors all year long. It is indispensable in mountains because it is highly resilient and can maintain high speed on the slopes and dangerous mountain paths. Hucul horses are especially significant for the development of the ecological tourism industry, and are gaining high popularity (Vysochans'ka, 2010).

The unique work and biological capacities of the horse allow its efficient usage in different ways for enterprises of all forms of property. Also, because of its calm temper and behaviour, good physical capacities, this horse is used for riding, equestrian sports, tourism and hippotherapy (a form of treatment which uses horses) in many countries of Europe (Clarke et al., 1987; Barton et al., 2003; Stefurak, 2004; Fielding et al., 2009).

Horses' diseases have been recently studied in Ukraine by a number of scholars (Golovaha, 2004; Piddubnjak and Golovaha, 2008; Bayeva and Zhegunov, 2016), but the holocoenotic pathologies of horses have been given too little consideration.

The biogeochemical province of Zakarpattia is characterized by specific peculiarities the significant microelements it contains. Certain elements are in poor supply, and the consequences this lack, which are often observed in different districts of Carpathians, require additional study (Rud'ko and Macijevs'ka, 2009). Therefore complex studies, which are based on determining the content of microelements in soil, fodder and the blood of animals, research on hematopoiesis and the condition of metabolism, and on efficient ways of correcting the disorders found are of scientific-practical significance.

Pregnancy is a physiological condition of the mare's organism, which is characterized by the connection of the organism of mother and fetus, and providing the latter with growth and development. During pregnancy, mares are highly sensitive to changes in feeding, conditions of their maintenance and their treatment, for their organisms are affected by certain changes in all metabolic chains. This is especially significant for mares in the final months of pregnancy, which are characterized by intense usage of mineral, energy metabolism and anabolism of the mother's organism for the development of body tissues of the fetus (Anderson, 1975; Wingfield, 1984; Barrelet and Ricketts, 2002; Takasu et al., 2013; Bazzano et al., 2014; Kryvda, 2016; Tkachev et al., 2016).

Soils and water resources in Zakarpattia oblast lack mobile forms of cobalt, zinc, and by lack of copper and manganese in some places (Shherbatyj et al., 2013). Lack of macro- and microelements in soil, fodder and water is a significant etiological factor of microelementosis of horses (Hinchcliff et al., 2002; Bishop, 2004; Lacerda et al., 2006; Gerber et al., 2014; Lucenko and Petrushko, 2015). For pregnant horses this is especially significant, for the last trimester involves intense development of $60-65 \%$ of body tissues of the fetus. At the same time, mares' need for nutritively and biologically active substances rises by $20 \%$, and by $40-50 \%$ during the winter-spring period.

Biologically active substances used for prevention and treatment of a number of animal diseases are especially significant 
for development of livestock (Martyshuk et al., 2016; Khariv and Gutyj, 2016; Khariv et al., 2016). So called mixed fodder and premixes are widely used for these purposes.

Usage of premixes is relevant and contributes to efficient treatment and prevention of pathologies of mineral metabolism of pregnant mares.

The aim of this research was to develop, test and justify a method of correcting microelemental weakness of pregnant Hucul horses through the experiments.

\section{Materials and methods}

The research was conducted at the scientific and production association "Plemkonezentr" (Zakarpattia oblast). As material, the research used pregnant Hucul horses aged between 4-18 years, and $400-450 \mathrm{~kg}$ in body mass. The research objects were blood and serum. All mares were kept in the same conditions of maintenance and feeding. While conducting research, we abided the rules necessary for zootechnical experiments on selection and maintenance of analogues-animals in groups, for technology of preparation, usage and account of food consumption. On the basis of the research conducted we developed the compound of mineral-vitamin premix MVP (mineral-vitamin premix) Marmix (Shherbatyj and Slivinska 2013), and experimentally proved its treatment and prevention efficiency.

For this purpose, we formed two groups of mares experimental and control group, 10 animals in each group, which were in the 9th month of pregnancy. Research on the efficiency of MVP Marmix on pregnant horses was conducted in comparison with indicators of pregnant horses with manifestations of disorders of mineral metabolism, which received a basic diet (control group), which includes $(\mathrm{kg})$ : hay from cultivated hayfields -2.5 , high mountain hay -2 , meadow hay -2.5 , wheat middlings -0.5 , corn middlings -1 , oat seeds -1 , press cake of sunflower -0.5 , dried, granular beet pulp -1 . Each horse consumed about $30.3 \pm 0.211$ of water a day, obtained from an Artesian well.

The mares of the experimental group, apart from the basic diet (BD) received MVP Marmix ("EGO" enterprise product) at the time of morning feeding, the amount calculated at $100 \mathrm{~g}$ a day over 60 days. One kilogram of the premix includes: vitamin $\mathrm{A}$ 250,000 ME, $\mathrm{D}_{3}-25,000 \mathrm{ME}, \mathrm{E}-6,000 \mathrm{mg}, \mathrm{B}_{1}-400, \mathrm{~B}_{2}-300$, pantothenic acid -300 , niacin -700 , biotin -175 , ascorbic acid 600; mineral substances: zinc $-750 \mathrm{mg}$, iron -1100 , copper -180 , manganese -1200 , iodine $-7,5$, selenium -2.5 , cobalt $-25 \mathrm{mg}$; amino acids: lysin $-1.5 \%$, threonine $-0.75 \%$, methionine $-1.0 \%$, filling agent (wheat middling - up to $1 \mathrm{~kg}$ ). During the experiment, the animals were clinically observed. Blood samples were taken from the jugular vein before the experiment, and also 45 and 60 days after feeding with the premix.

Clinical study of the mares was conducted according to generally accepted methods (Levchenko et al., 2010).

General clinical analysis of blood included the calculation of erythrocytes and leukocytes (in the haemocytometer with grid), of hematocrit - by microcentrifuge (by Shkliar), content of hemoglobin using the hemiglobincyanide method, ESR - according to T. P. Panchenko. Using the results, we calculated the average volume of erythrocytes (MCV) and the content of hemoglobin in a single erythrocyte (MCH) (Levchenko et al., 2010).

The content of copper and cobalt in the blood serum of the mares was defined by the method of atomic absorption spectroscopy using AAS-30.

The protein-synthesizing function of the liver was determined according to the level of total protein (biuret reaction) in the blood serum, enzymic function - according to the activity of aspartate (AST) and alanine (ALT) aminotransferase, using the method of Frankel (Reitman and Frankel, 1957), $\alpha$-amylase (method of Caraway, 1986), alkaline phosphate (AP) - by the reaction of disodium phenyl phosphate hydrolysis (Levchenko et al. , 2010). We determined the concentration of glucose in the blood plasma through o-toluidine, urea - through Diacetyl monoxime, creatinine by Jaffe colorimetric reaction (Levchenko et al., 2010). The content of non-organic phosphorus in the blood serum was determined using the method of Dyce and Bessman, 1973, and total calcium was determined by calcium arsenazo-III (Levchenko et al., 2010).

The content of vitamins $\mathrm{A}$ and $\mathrm{E}$ in the blood serum was studied using liquid chromatograph Milichrom-5.

All manipulations with the animals were conducted in accordance with the European Convention for the Protection of Vertebrate Animals used for Experimental and Other Scientific Purposes (Strasburg, 1986). Mathematical analysis was made in Statistica 6.0 (StatSoft Inc., USA). Differences between the average values were considered statistically significant at $\mathrm{P}<0.05$ (ANOVA).

\section{Results and discussion}

In the experimental and control groups, on the 60th day of the experiment, we observed manifestations of positive changes in the condition of pelage (restoration of luster, absence of depigmentation, uniformity of moult), of visible mucous membranes, heart tones, digestive system, indicators of haematopoiesis, metabolism of macro- and microelements, lipid peroxidation, functional condition of the liver and kidneys.

The study of erythropoiesis indicators showed no positive changes in the control group of mares: the number of erythrocytes did not change, and the content of hemoglobin decreased $(\mathrm{P}<0.05)$. The mares of the experimental group had opposite results (Table 1).

\section{Table 1}

The influence of Marmix premix on hematologic indicators of pregnant during the experiment $(\mathrm{x} \pm \mathrm{SE})$

\begin{tabular}{|c|c|c|c|c|c|c|}
\hline \multirow[b]{3}{*}{ Indicator } & \multicolumn{6}{|c|}{ Groups } \\
\hline & \multicolumn{3}{|c|}{ control $(n=10)$} & \multicolumn{3}{|c|}{ experimental $(n=10)$} \\
\hline & $\begin{array}{l}\text { beginning } \\
\text { of the ex- } \\
\text { periment }\end{array}$ & 45th day & $\begin{array}{l}\text { 60th } \\
\text { day }\end{array}$ & $\begin{array}{l}\text { beginning } \\
\text { of the ex- } \\
\text { periment }\end{array}$ & 45th day & 60th day \\
\hline $\begin{array}{c}\text { Erythrocytes, } \\
\text { T/1 }\end{array}$ & $\begin{array}{l}5.7 \pm \\
0.32\end{array}$ & $\begin{array}{l}5.9 \pm \\
0.16\end{array}$ & $\begin{array}{l}5.3 \pm \\
0.17\end{array}$ & $\begin{array}{l}5.8 \pm \\
0.10\end{array}$ & $\begin{array}{c}7.1 \pm \\
0.13 \\
\mathrm{P}<0.001\end{array}$ & $\begin{array}{l}7.3 \pm 0.11 \\
\mathrm{P}_{2}<0.001 \\
\mathrm{P}_{3}<0.001\end{array}$ \\
\hline $\begin{array}{l}\text { Hemoglobin, } \\
\mathrm{g} / 1\end{array}$ & $\begin{array}{c}91.6 \pm \\
2.26\end{array}$ & $\begin{array}{l}84.2 \pm \\
2.02 \\
\mathrm{P}_{5}< \\
0.05\end{array}$ & $\begin{array}{c}83.4 \pm \\
1.78 \\
\mathrm{P}_{4}< \\
0.05\end{array}$ & $\begin{array}{c}90.7 \pm \\
0.40\end{array}$ & $\begin{array}{c}115.1 \pm \\
2.48 \\
\mathrm{P}<0.001\end{array}$ & $\begin{array}{c}122.0 \pm 1.95 \\
\mathrm{P}_{1}<0.05 \\
\mathrm{P}_{2}<0.001 \\
\mathrm{P}_{3}<0.001\end{array}$ \\
\hline $\begin{array}{c}\text { The content of } \\
\text { hemoglobin in } \\
\text { one erythrocyte } \\
(M C H), p g\end{array}$ & $\begin{array}{c}15.8 \pm \\
0,48\end{array}$ & $\begin{array}{l}14.1 \pm \\
0.35 \\
\mathrm{P}_{5}< \\
0.05\end{array}$ & $\begin{array}{c}15.5 \pm \\
0.45\end{array}$ & $\begin{array}{c}16.1 \pm \\
0.31\end{array}$ & $\begin{array}{c}16.0 \pm \\
0.52\end{array}$ & $\begin{array}{c}16.5 \pm \\
0.26\end{array}$ \\
\hline
\end{tabular}

Note: $\mathrm{P}-45$ th day compared to the beginning of experiment; $\mathrm{P}_{1}-60$ th day compared to 45 th day in the experimental group; $\mathrm{P}_{2}-60$ th day in the experimental group compared to 60th day in control group; $\mathrm{P}_{3}-60$ th day compared to the beginning of the experiment; $\mathrm{P}_{4}-60$ th day compared to the first day in the control group; $\mathrm{P}_{5}-45$ th day compared to the first day in the control group; in other cases, the difference was insignificant.

The number of erythrocytes at the beginning of the experiment was on average $5.8 \pm 0.10 \mathrm{~T} / \mathrm{l}$, which is below norm (6.0-9.0 T/l). By the 45th day, the number of erythrocytes had significantly $(\mathrm{P}<0.001)$ increased by $22.0 \%(7.1 \pm 0.13 \mathrm{~T} / \mathrm{l})$, after the experiment - by $25.4 \%$ $(\mathrm{P}<0.001)$ compared to the beginning of the experiment and by $11.7 \%$ and $37.0 \%(\mathrm{P}<0.001)$ on 45 th and 60 th days compared to mares of the control group.

Along with the growing number of erythrocytes, the blood of mares from the experimental group had an increasing content of hemoglobin compared to the beginning of the experiment and control group. The content of the animals' hemoglobin at the beginning of the experiment was at the lower physiological margin and was $94.8 \pm 0.40 \mathrm{~g} / \mathrm{l}$ on average. $10 \%$ of mares had the hemoglobin content below the norm. 45 days later, the content of hemoglobin had significantly $(\mathrm{P}<0.001)$ increased by $21.5 \%$ compared to the beginning of the experiment. After the end of experiment (60 days) the content of hemoglobin on average was $122.0 \pm 1.95 \mathrm{~g} / 1$, which was $28.7 \%$ higher $(\mathrm{P}<0,001)$, than at the beginning of the experiment, higher by $5.9 \%(\mathrm{P}<0.05)$ compared to the 
45th day, and $46.1 \%$ higher than in the control group $(\mathrm{P}<0.001)$. It should be mentioned that there were no significant differences in the number of erythrocytes of mares from the control group compared to the beginning of the experiment, and the content of hemoglobin significantly decreased by $8.9 \%(\mathrm{P}<0.05)$.

On the 45th and 60th days, the MCH of the animals from the experimental group did not change. By the end of experiment, it had stabilized at the initial level $(+2.5 \%$; $\mathrm{P}<0.05)$.

Nevertheless, the average content of hemoglobin in a single erythrocyte of mares from the experimental group was slightly higher than in the control group, where it was $10.8 \%(\mathrm{P}<0.01)$ lower at the 45th day of the experiment compared to the beginning of the experiment, and on the 60th day - lower by $1.9 \%$. The difference of $\mathrm{MCH}$ between the mares from the experimental and control groups was $22.0 \%$ and $6.5 \%$ on 45 th $(\mathrm{P}<0.01)$ and 60 th days of the experiment.

The hematocrit of pregnant mares from the control group remained stable during the experiment; in the experimental group, it gradually increased from $0.32 \pm 0.01$ to $0.36 \pm 0.051 / 1$ on the 45th day and $0.40 \pm 0.01$ on the 60th day $(\mathrm{P}<0.001)$, i.e. by 11.1 and $20.0 \%(\mathrm{P}<0.001)$. The experiment's final indicator was $21.2 \%$ higher than in the control group (Table 2).

Table 2

The influence of Marmix premix on the correction of hematologic indicators of pregnant mares during the experiment $(x \pm S E)$

\begin{tabular}{|c|c|c|c|c|c|c|}
\hline \multirow[b]{3}{*}{ Indicator } & \multicolumn{6}{|c|}{ Groups } \\
\hline & \multicolumn{3}{|c|}{ control $(n=10)$} & \multicolumn{3}{|c|}{ experimental $(n=10)$} \\
\hline & $\begin{array}{l}\text { beginning } \\
\text { of the ex- } \\
\text { periment }\end{array}$ & $\begin{array}{l}\text { 45th } \\
\text { day }\end{array}$ & 60th day & $\begin{array}{l}\text { beginning } \\
\text { of the ex- } \\
\text { periment }\end{array}$ & 45th day & 60th day \\
\hline Hematocrit, 1/1 & $\begin{array}{c}0.33 \pm \\
0.10\end{array}$ & $\begin{array}{c}0.34 \pm \\
0.01\end{array}$ & $\begin{array}{c}0.33 \pm \\
0.01\end{array}$ & $\begin{array}{c}0.32 \pm \\
0.01\end{array}$ & $\begin{array}{c}0.36 \pm \\
0.05\end{array}$ & $\begin{array}{c}0.40 \pm 0.01 \\
\mathrm{P}_{1}<0.001 \\
\mathrm{P}_{2}<0.001\end{array}$ \\
\hline $\begin{array}{l}\text { Average volu- } \\
\text { me of eryth- } \\
\text { rocytes, } \mu \mathrm{m}^{3}\end{array}$ & $\begin{array}{c}56.9 \pm \\
2.10\end{array}$ & $\begin{array}{c}56.7 \pm \\
2.90\end{array}$ & $\begin{array}{c}61.1 \pm \\
26.5 \\
\mathrm{P}_{3}<0.05\end{array}$ & $\begin{array}{c}54.2 \pm \\
2.00\end{array}$ & $\begin{array}{c}55.2 \pm \\
1.24\end{array}$ & $54.1 \pm 1.50$ \\
\hline ESR, mm/year & $\begin{array}{c}56.4 \pm \\
1.02\end{array}$ & $\begin{array}{c}56.6 \pm \\
1.18\end{array}$ & $\begin{array}{c}57.2 \pm \\
0.77\end{array}$ & $\begin{array}{c}46.4 \pm \\
3.51\end{array}$ & $\begin{array}{c}60.6 \pm \\
0.64 \\
P<0.001 \\
\end{array}$ & $\begin{array}{c}62.1 \pm 0.53 \\
\mathrm{P}_{1}<0.001 \\
\mathrm{P}_{2}<0.001 \\
\end{array}$ \\
\hline
\end{tabular}

Note: $\mathrm{P}-45$ th day compared to the beginning of experiment in the experimental group; $\mathrm{P}_{1}-60$ th day in the experimental group compared to the control group on the 60th day; $\mathrm{P}_{2}-60$ th day in the experimental group compared to the beginning of experiment; $\mathrm{P}_{3}-60$ th day in the control group compared to the beginning of the experiment.

The increase in hematocrit of mares from the experimental group occurred as a result of increase in the number of erythrocytes, for their average volume (MCV) remained stable. On the 45th and 60th days of the experiment, we observed a significant $(\mathrm{P}<0.001)$ increase of ESR by 1.31 and 1.34 times respectively.

The last months of mares' pregnancy is characterized by intense usage of mineral, energy metabolism and anabolism of the mother for forming the body tissues of the fetus (Hunter et al., 2001; Scantlebury et al., 2014). Therefore the study of changes in the indicators of macro- and microelements is especially significant.

45 days after the start of the experiment, the level of calcium showed a tendency to decrease $(\mathrm{P}<0.1)$ from $3.31 \pm 0.10$ to $3.02 \pm$ $0.14 \mathrm{mmol} / \mathrm{l}$, and on 60th day, we observed a significant $(\mathrm{P}<0.001)$ decrease in its content by $13.9 \%$ compared to the beginning of the experiment, although the difference with the previous study was not significant. The content of calcium in the blood serum of mares from the experimental group was lower than in the control on the 45th and 60th days, by $9.9 \%$ and $13.6 \%$ respectively (Table 3 ).

Possible changes in the content of non-organic phosphorus of pregnant mares from the control group were not observed. In contrast, we observed increase in the content of macroelement among mares from the experimental group after usage of premix by $15.9 \%$ compared to the initial level, and by $21.7 \%$ compared to 45 th day.

The content of phosphorus in the blood serum of mares from experimental group on the 60 th day was $17.7 \%$ higher than in the control group $(\mathrm{P}<0.001)$. The calcium-phosphorus ratio on the 45th day on average was $2.53 \pm 0.14$, by the end of the experiment $2.06 \pm 0.10$ and was significantly $(\mathrm{P}<0.05)$ lower compared to the 45th day and beginning of experiment $(\mathrm{P}<0.01)$, which indicates the metabolism of macroelements.

Table 3

The influence of Marmix premix on the content of macroelements in the blood of pregnant mares during the period of the experiment $(x \pm S E)$

\begin{tabular}{|c|c|c|c|c|c|c|}
\hline \multirow[b]{3}{*}{ Indicator } & \multicolumn{6}{|c|}{ Groups } \\
\hline & \multicolumn{3}{|c|}{ control $(n=10)$} & \multicolumn{3}{|c|}{ experimental $(n=10)$} \\
\hline & $\begin{array}{c}\text { beginning } \\
\text { of the } \\
\text { experime } \\
\text { nt }\end{array}$ & 45th day & 60th day & $\begin{array}{l}\text { beginning } \\
\text { of the } \\
\text { experiment }\end{array}$ & 45th day & 60th day \\
\hline $\begin{array}{l}\text { Total Ca, } \\
\mathrm{mmol} / \mathrm{l}\end{array}$ & $\begin{array}{c}3.31 \pm \\
0.07\end{array}$ & $\begin{array}{c}3.35 \pm \\
0.06\end{array}$ & $\begin{array}{l}3.31 \pm 0.05 \\
P_{3}<0.001\end{array}$ & $\begin{array}{c}3.32 \pm \\
0.10\end{array}$ & $\begin{array}{c}3.02 \pm \\
0.14\end{array}$ & $\begin{array}{c}2.86 \pm 0.05 \\
P_{2}<0.001\end{array}$ \\
\hline $\begin{array}{c}\text { Non- } \\
\text { organic } \mathrm{P} \text {, } \\
\mathrm{mmol} / \mathrm{l}\end{array}$ & $\begin{array}{c}1.22 \pm \\
0.05\end{array}$ & $\begin{array}{c}1.19 \pm \\
0.05\end{array}$ & $\begin{array}{l}1.24 \pm 0.05 \\
\mathrm{P}_{3}<0.001\end{array}$ & $\begin{array}{c}1.26 \pm \\
0.12\end{array}$ & $\begin{array}{c}1.20 \pm \\
0.04\end{array}$ & $\begin{array}{c}1.46 \pm 0.02 \\
\mathrm{P}_{1}<0.001\end{array}$ \\
\hline Ratio Ca:P & $\begin{array}{c}2.75 \pm \\
0.11\end{array}$ & $\begin{array}{c}2.85 \pm \\
0.14\end{array}$ & $\begin{array}{c}2.70 \pm 0.09 \\
\mathrm{P}_{3}<0.001\end{array}$ & $\begin{array}{c}2.78 \pm \\
0.20\end{array}$ & $\begin{array}{c}2.53 \pm \\
0.14\end{array}$ & $\begin{array}{c}2.06 \pm 0.10 \\
\mathrm{P}_{1}<0.05 \\
\mathrm{P}_{2}<0.01\end{array}$ \\
\hline AP, IU/1 & $\begin{array}{c}368.2 \pm \\
2.9\end{array}$ & $\begin{array}{c}337.6 \pm \\
3.1\end{array}$ & $\begin{array}{c}355.4 \pm 2.1 \\
\mathrm{P}_{2}<0.01 \\
\mathrm{P}_{3}<0.001\end{array}$ & $\begin{array}{c}380.3 \pm \\
2.3\end{array}$ & $\begin{array}{c}228.2 \pm \\
1.7 \\
\mathrm{P}<0.001\end{array}$ & $\begin{array}{c}214.0 \pm 2.3 \\
\mathrm{P}_{1}<0.001 \\
\mathrm{P}_{2}<0.001\end{array}$ \\
\hline
\end{tabular}

Note: $\mathrm{P}-45$ th day compared to the beginning of experiment in the experimental group; $\mathrm{P}_{1}-60$ th day in the experimental group in the experimental group compared with 45 th day; $\mathrm{P}_{2}-60$ th day compared to the beginning of experiment; $\mathrm{P}_{3}-60$ th day of experiment compared to the control group on the 60th day.

An important indicator of the stability of calcium-phosphorus metabolism in the animals' organism is the activity of AP. By the 45th and 60th days of the experiment, the activity of AP had significantly decreased by $40.0 \%$ and $43.7 \%(\mathrm{P}<0.001)$ respectively compared to the beginning of the experiment, and by $32.4 \%$ and $39.8 \%(\mathrm{P}<0.001)$ compared to the control.

Among the microelements in the diet of the pregnant mares which stimulate hematopoesis, those provided in the smallest quantities were manganese, copper and cobalt. Therefore, we conducted analysis of dynamics of $\mathrm{Co}$ and $\mathrm{Cu}$ under the influence of MVP Marmix.

The content of cobalt had already increased up to $0.48 \pm 0.02 \mu \mathrm{mol} / \mathrm{l}$ (by $29.7 \%$ ) by the 45 th day of the experiment compared to its initial value, and by $33.3 \%$ compared to the control. Further, the content of cobalt continued to increase and on the 60th day we observed a significantly $(\mathrm{P}<0.001)$ higher content of cobalt (by $45.9 \%)$ compared to the beginning (Table 4).

\section{Table 4}

The influence of Marmix premix on the content of microelements in the blood of pregnant mares during the experiment $(x \pm S E)$

\begin{tabular}{|c|c|c|c|c|c|c|}
\hline \multirow[b]{3}{*}{ Indicator } & \multicolumn{6}{|c|}{ Groups } \\
\hline & \multicolumn{3}{|c|}{ control OP $(n=10)$} & \multicolumn{3}{|c|}{ experimental $(n=10)$} \\
\hline & $\begin{array}{l}\text { beginning } \\
\text { of the } \\
\text { experiment }\end{array}$ & $\begin{array}{l}\text { 45th } \\
\text { day }\end{array}$ & 60th day & $\begin{array}{l}\text { beginning } \\
\text { of the } \\
\text { experiment }\end{array}$ & 45th day & 60th day \\
\hline $\begin{array}{c}\mathrm{Co}, \\
\mu \mathrm{mol} / \mathrm{l}\end{array}$ & $\begin{array}{c}0.35 \pm \\
0.01\end{array}$ & $\begin{array}{c}0.36 \pm \\
0.02\end{array}$ & $\begin{array}{c}0.34 \pm \\
0.02 \\
\mathrm{P}_{2}<0.001\end{array}$ & $\begin{array}{c}0.37 \pm \\
0.01\end{array}$ & $\begin{array}{c}0.48 \pm \\
0.02 \\
\mathrm{P}<0.001\end{array}$ & $\begin{array}{c}0.54 \pm \\
0.03 \\
\mathrm{P}_{1}<0.001\end{array}$ \\
\hline $\begin{array}{c}\mathrm{Cu}, \\
\mu \mathrm{mol} / \mathrm{l}\end{array}$ & $\begin{array}{c}2.43 \pm \\
0.34\end{array}$ & $\begin{array}{c}2.50 \pm \\
0.65\end{array}$ & $\begin{array}{c}2.65 \pm \\
0.46 \\
\mathrm{P}_{2}<0.001\end{array}$ & $\begin{array}{c}2.80 \pm \\
0.50\end{array}$ & $\begin{array}{c}5.35 \pm \\
0.32 \\
\mathrm{P}<0.001\end{array}$ & $\begin{array}{c}6.01 \pm \\
0.18 \\
\mathrm{P}_{1}<0.001\end{array}$ \\
\hline $\begin{array}{c}\mathrm{Fe}, \\
\mu \mathrm{mol} / \mathrm{l}\end{array}$ & $\begin{array}{c}19.3 \pm \\
0.85\end{array}$ & $\begin{array}{c}21.0 \pm \\
1.29\end{array}$ & $\begin{array}{c}22.1 \pm \\
1.78\end{array}$ & $\begin{array}{c}21.6 \pm \\
0.71\end{array}$ & $\begin{array}{c}24.2 \pm \\
0.80 \\
\mathrm{P}_{1}<0.05\end{array}$ & $\begin{array}{c}21.1 \pm \\
1.42\end{array}$ \\
\hline
\end{tabular}

Note: $\mathrm{P}-45$ th day compared to the beginning of experiment in the experimental group; $\mathrm{P}_{1}-60$ th day compared to the beginning of experiment; $\mathrm{P}_{2}-$ 60 th day of experiment compared to the control group on 60th day.

Its average content in the blood of animals from the experimental group was $0.54 \pm 0.03 \mu \mathrm{mol} / \mathrm{l}$, which was significantly $(\mathrm{P}<0.001)$ higher by $58.8 \%$ compared to indicators of mares from the control group. Feeding with MVP caused significant growth in the content of copper in the blood of pregnant mares. On the 45th day of experiment, the 
level of copper in mares' blood was higher by $5.35 \pm 0.32 \mu \mathrm{mol} / 1$ on average, which was 1.91 times higher $(\mathrm{P}<0.001)$ compared to the beginning of experiment, and by 2.14 times compared with the control.

The content of copper continued to increase and at the end of the experiment its level in the blood of mares from the experimental group was $6.01 \pm 0.18 \mu \mathrm{mol} / 1$, which was $114.6 \%$ higher compared to its content at the beginning of the experiment, and by $126.8 \%$ higher compared to the control. Compared to the 45th day, the content of copper had a tendency to increase by $11.0 \%$.

The increase in the level of cobalt and copper in the organism of pregnant mares caused a positive effect on the indicators of hematopoiesis. The mares' symptoms of anemia disappeared, and the amount of erythrocytes and hemoglobin increased. Cobalt and copper positively influenced the process of hematopoiesis by stabilizing the content of hemoglobin in a single erythrocyte and eliminating anemia.

During all period of the experiment, the content of iron in the blood of pregnant mares from all groups remained within the range of physiological fluctuations (13.0-25.0 $\mu \mathrm{mol} / \mathrm{l})$. By the end of the experiment (60th day), the content of iron stabilized at the level of $21.1 \pm 1.42 \mu \mathrm{mol} / \mathrm{l}$, which is significantly $(\mathrm{P}<0.05)$ lower by $12.8 \%$ compared to the 45 th day. In our opinion, the decrease in the amount of iron by the end of experiment was conditioned by its intense usage during the final term of pregnancy. The amount of iron in blood serum during the experiment was within the norm.

The content of total protein of horses from the experimental group by the 45th day of the experiment had significantly $(\mathrm{P}<0.001)$ increased by $19.4 \%$. This positive tendency continued: on the 60 th day, protein equaled $73.6 \pm 0.86 \mathrm{~g} / 1-7.0 \%$ higher than on day $45,0 \%$ and $42.1 \%$ higher compared to the control group (Table 5).

\section{Table 5}

The influence of MVP Marmix on the indicators of metabolism among pregnant mares $(\mathrm{x} \pm \mathrm{SE})$

\begin{tabular}{|c|c|c|c|c|c|c|}
\hline \multirow[b]{3}{*}{ Indicator } & \multicolumn{6}{|c|}{ Groups } \\
\hline & \multicolumn{3}{|c|}{ control $(n=10)$} & \multicolumn{3}{|c|}{ experimental $(\mathrm{n}=10)$} \\
\hline & $\begin{array}{l}\text { beginning } \\
\text { of the ex- } \\
\text { periment }\end{array}$ & 45th day & y & $\begin{array}{l}\text { beginning } \\
\text { of the ex- } \\
\text { periment }\end{array}$ & 45th day & 60 th \\
\hline $\begin{array}{c}\text { Total } \\
\text { protein, g/l }\end{array}$ & $\begin{array}{c}55.2 \pm \\
1.04\end{array}$ & $\begin{array}{c}51.8 \pm \\
1.20\end{array}$ & $\begin{array}{c}52.4 \pm \\
1.12 \\
\mathrm{P}_{3}<0.001\end{array}$ & $\begin{array}{c}57.6 \pm \\
0.84\end{array}$ & $\begin{array}{c}68.8 \pm \\
1.55 \\
\mathrm{P}_{2}<0.001\end{array}$ & $\begin{array}{l}\mathrm{P}<0.001 \\
\mathrm{P}_{1}<0.05\end{array}$ \\
\hline $\begin{array}{c}\text { Urea } \\
\mathrm{mmol} / \mathrm{l}\end{array}$ & $\begin{array}{l}7.6 \pm \\
0.24\end{array}$ & $\begin{array}{l}7.5 \pm \\
0.20\end{array}$ & $\begin{array}{c}7.4 \pm \\
0.17 \\
\mathrm{P}_{3}<0.01\end{array}$ & $\begin{array}{c}8.1 \pm \\
0.36\end{array}$ & $\begin{array}{c}6.6 \pm \\
0.31 \\
\mathrm{P}_{2}<0.01\end{array}$ & $\begin{array}{c}4.7 \pm 0.85 \\
\mathrm{P}<0.01 \\
\mathrm{P}_{1}<0.05\end{array}$ \\
\hline $\begin{array}{l}\text { Creatinine, } \\
\mu \mathrm{mol} / \mathrm{l}\end{array}$ & $\begin{array}{c}127.2 \pm \\
3.5\end{array}$ & $\begin{array}{c}133.9 \pm \\
2.7\end{array}$ & $\begin{array}{c}129.1 \pm \\
1.9 \\
\mathrm{P}_{3}<0.001\end{array}$ & $\begin{array}{c}134.1 \pm \\
3.5\end{array}$ & $\begin{array}{c}128.8 \pm \\
3.9\end{array}$ & $\begin{array}{c}112.6 \pm 2.5 \\
\mathrm{P}<0.001 \\
\mathrm{P}_{1}<0.01\end{array}$ \\
\hline $\begin{array}{c}\text { AspAT, } \\
\text { IU/1 }\end{array}$ & $\begin{array}{c}270.9 \pm \\
2.5\end{array}$ & $\begin{array}{c}281.3 \pm \\
1.1\end{array}$ & $\begin{array}{c}273.3 \pm \\
4.6 \\
\mathrm{P}_{3}<0.001\end{array}$ & $\begin{array}{c}245.2 \pm \\
3.6\end{array}$ & $\begin{array}{c}207.6 \pm \\
3.8 \\
\mathrm{P}_{2}<0.001\end{array}$ & $\begin{array}{c}140.3 \pm 1.8 \\
\mathrm{P}<0.001 \\
\mathrm{P}_{1}<0.001\end{array}$ \\
\hline AlAT, IU/l & $\begin{array}{c}17.3 \pm \\
0.74\end{array}$ & $\begin{array}{c}17.1 \pm \\
0.63\end{array}$ & $\begin{array}{c}16.8 \pm \\
0.71 \\
\mathrm{P}_{3}<0.001 \\
\end{array}$ & $\begin{array}{c}18.7 \pm \\
0.88\end{array}$ & $\begin{array}{c}13.4 \pm \\
0.70 \\
\mathrm{P}_{2}<0.001 \\
\end{array}$ & $\begin{array}{c}10.3 \pm 0.76 \\
\mathrm{P}<0.001 \\
\mathrm{P}_{1}<0.01\end{array}$ \\
\hline
\end{tabular}

Note: $\mathrm{P}$ - compared to the beginning of experiment in the experimental group; $\mathrm{P}_{1}-60$ th day compared to 45 th day in the experimental group; $\mathrm{P}_{2}-$ 45 th day of the experiment compared to the beginning of the experiment; $\mathrm{P}_{3}-$ the end of the experiment compared to the control group.

The data obtained indicate a great activation of protein metabolism in the organism of mares during pregnancy under the influence of the premix. The usage of MVP Marmix allows the protein metabolism in the organism of pregnant mares to remain at a quite high level, which is necessary for process of broodmares' vital functions, for growth and development of the fetus (Shherbatyj et al., 2013).

The urea content of $100 \%$ of mares from the control and experimental groups at the beginning was excessive, and average indicators did not significantly differ. Later in the experiment, it remained stable for mares in the control group, and gradually decreased in the experimental group to $6.6 \pm 0.31 \mathrm{mmol} / \mathrm{l}$ on the 45th day $(-18.5 \% ; \mathrm{P}<0.01)$ and $4.7 \pm 0.85 \mathrm{mmol} / \mathrm{l}-$ on the 60 th day $(-42 \% ; \mathrm{P}<0.01)$. The difference with the previous indicator is considered significant at $(\mathrm{P}<0.05)$. After the end of the experiment of feeding pregnant mares with the premix, there were no mares with azotemia in the experimental group, whereas in the control group $90 \%$ of mares had azotemia. The difference in the content of urea was $36.5 \%(\mathrm{P}<0.01)$.

In the blood serum of mares from both groups the concentration of creatinine remained within the range of physiological fluctuations (100$160 \mu \mathrm{mol} / \mathrm{l})$ throughout experiment. However, in the experimental group, we observed a gradual significant decrease in its level and on 60th day, the concentration of creatinine was $112.6 \pm 2.5 \mu \mathrm{mol} / 1(\mathrm{P}<0.001)-$ lower by $16.0 \%$ and $12.8 \%(\mathrm{P}<0.001)$ than at the beginning of experiment and lower than the indicator in the control group on the 60th day. Therefore, the content of urea and creatinine in the blood serum indicate optimum filtrating function of the kidneys.

An important stage in studying the preparation is the study of changes in the liver. An objective criterion of the condition of hepatocytes, their membranes, is the activity of indicative enzymes, particularly AspAT and AlAT (Lindner and Hatzipanagiotou, 1998; Wood, 2004; Lindner et al., 2009; Adamu et al., 2010; Muñoz et al., 2012). By the 45th day, the activity of AspAT in the experimental group had significantly $(\mathrm{P}<0.001)$ decreased by $15.3 \%$ and on average was $207.6 \pm 3.85 \mathrm{IU} / 1$, and after the end of experiment, it was significantly $(\mathrm{P}<0.001)$ lower by $42.9 \%$ and $32.4 \%$ compared to the beginning and the 45th day, two times $(\mathrm{P}<0.001)$ lower compared to the control group. Therefore, the preparation does not cause structural changes in hepatocytes. On the contrary, the activity of AspAT decreases, which indicates the normalizing of structure and function of liver cells. By the 45th and 60th days of the experiment, the activity of another hepato-indicative enzyme AlAT had also significantly $(\mathrm{P}<0.001$ ) decreased by $28.3 \%$ and $44.9 \%$ compared to the beginning of the experiment, and by $38.7 \%$ $(\mathrm{P}<0.001)$ compared to the control group.

A significant element of the antioxidative system is vitamins A and $\mathrm{E}$ rather than the enzymic component (Lavryshyn et al., 2016; Gutyj et al., 2016; Padalino et al., 2017). Our research showed that the content of vitamin A in the blood serum of pregnant mares at the beginning of the experiment was 1.64 times lower than the minimum norm, and by the 45th day had significantly $(\mathrm{P}<0.01)$ increased by $43.9 \%$ compared to the beginning of the experiment, and was on average $0.57 \pm 0.07 \mathrm{mmol} / \mathrm{l}$ (Table 6). The content of vitamin A recovered among $70 \%$ of mares. By the 60 th day, the level of retinol had continued to increase and significantly increased by $2.5(\mathrm{P}<0.001)$ and $2.35(\mathrm{P}<0.01)$ times compared to the beginning of the experiment and control respectively.

Table 6

The influence of Marmix premix on the content of vitamins A and $\mathrm{E}$ in the blood of pregnant mares during the experiment $(\mathrm{x} \pm \mathrm{SE})$

\begin{tabular}{|c|c|c|c|c|c|c|}
\hline \multirow[b]{3}{*}{ Indicator } & \multicolumn{6}{|c|}{ Groups } \\
\hline & \multicolumn{3}{|c|}{ control $(n=10)$} & \multicolumn{3}{|c|}{ experimental $(n=10)$} \\
\hline & $\begin{array}{l}\text { beginning } \\
\text { of the ex- } \\
\text { periment }\end{array}$ & 45th day & & $\begin{array}{l}\text { beginning } \\
\text { of the ex- } \\
\text { periment }\end{array}$ & $45 t$ & 60 \\
\hline $\begin{array}{c}\text { Vitamin } \\
\mathrm{A}, \mu \mathrm{mol} / \mathrm{l}\end{array}$ & $\begin{array}{c}0.33 \pm \\
0.18\end{array}$ & $\begin{array}{c}0.36 \pm \\
0.12\end{array}$ & $\begin{array}{c}0.34 \pm \\
0.14 \\
\mathrm{P}_{3}<0.01\end{array}$ & $\begin{array}{c}0.32 \pm \\
0.02\end{array}$ & $\begin{array}{c}0.57 \pm \\
0.07 \\
\mathrm{P}<0.01\end{array}$ & $\begin{array}{c}0.80 \pm 0.05 \\
\mathrm{P}_{1}<0.05 \\
\mathrm{P}_{2}<0.001\end{array}$ \\
\hline $\begin{array}{c}\text { Vitamin } \\
\mathrm{E}, \mu \mathrm{mol} / 1\end{array}$ & $\begin{array}{c}4.48 \pm \\
0.20\end{array}$ & $\begin{array}{c}4.94 \pm \\
0.45\end{array}$ & $\begin{array}{c}4.21 \pm \\
0.36 \\
\mathrm{P}_{3}<0.001\end{array}$ & $\begin{array}{c}4.70 \pm \\
1.16\end{array}$ & $\begin{array}{c}9.01 \pm \\
1.02 \\
\mathrm{P}<0.05\end{array}$ & $\begin{array}{c}9.5 \pm 1.13 \\
\mathrm{P}_{2}<0.01\end{array}$ \\
\hline
\end{tabular}

Note: $\mathrm{P}-45$ th day compared to the beginning of the experiment; $\mathrm{P}_{1}-60$ th day compared to 45 th day in experimental group; $\mathrm{P}_{2}-60$ th day compared to the beginning of the experiment; $\mathrm{P}_{3}-60$ th day of experiment compared to the control group on 60th day.

Vitamin A was within the norm among all mares. In the control group, the content of retinol in the end of experiment was $0.34 \pm$ $0.14 \mu \mathrm{mol} / \mathrm{l}$, which is lower than the lower margin of physiological range $(0.52 \mu \mathrm{mol} / \mathrm{l})$ by $34.6 \%$. Along with the level of vitamin $\mathrm{A}$, under the influence of MVP Marmix, the blood serum of experimental mares had an increasing level of tocopherol. Increase $(\mathrm{P}<0.05)$ in the content 
of vitamin $\mathrm{E}$ in the blood of pregnant mares from the experimental group was observed already on the 45 th day, and by the 60th day, it had increased by $101.3(\mathrm{P}<0.01)$ and $124.7 \%(\mathrm{P}<0.001)$ compared to the beginning of the experiment and the indicator of control group.

The level of tocopherol of all mares on the 60th day of the experiment was within the norm. The average content of tocopherol of mares from the control group throughout the experiment was lower than the norm almost by 1.7 times and on average on the 60th day equaled $4.21 \pm 0.36 \mu \mathrm{mol} / \mathrm{l}$. Thus, usage of MVP Marmix on pregnant mares during 60 days increased the level of vitamins $A$ and $E$.

The data obtained indicate the positive effect of Marmix preparation on recovery of the $\mathrm{A}$ and $\mathrm{E}$ vitamin metabolism.

The research conducted indicates that feeding preganant mares on a diet which lacks a balance in the main nutrient substances, decreases digestion of energetic and anabolic material, causes disorders of digestion processes, metabolic processes and causes decrease in blood indicators. The lack microelements in the animals' diet, espessially during the reproduction period, significantly affects pregnancy, birth and the quality of offspring. Negative external factors have a cumulative effect on the biological peculiarities of pregnant animals and, in combination, cause excessive tension in their organism, which leads to a decrease in its anabolic, energetic and immune substances. In these conditions, the organism of the fetus receives less oxygen and nutritive substances per unit of time. This leads to decrease in the qualitative indicators of young animals and weakening of their resistance to diseases.

Screening is a progressive form of veterinary service for horses, allows pathologies of animals at to be diagnosed at subclinical stages of development and efficient treatment and prevention measures to be taken. According to the results of screening, the development and introduction of a complex of organizational and treatment-preventive measures, feeding with Marmix mineral-vitamin premix of Ukrainian production prevents microelemetosis and hypovitaminosis, restores the structure and function of liver and kidneys, vitamin A and E and phosphorus-calcium metabolism of mares from the Plemkonezentr. Marmix premix is a mix of chemical components which are characterized with a certain mechanism of influencing the metabolism. The ratio of components in the preparations is based on their prophylactic doses and osmotic properties. According to their physical and chemical properties, the components of the premix are compatible as synergists.

The research conducted contributes to the study of the pathogenesis of microelementosis among mares in greater detail and to the development of an efficient system of treatment of animals for microelementosis.

\section{Conclusions}

For the treatment of pregnant mares under hypocobaltosis and hypocuprosis and for prevention of microelementosis in the biogeochemical province of Zakarpattia, we suggest using Marmix mineral-vitamin premix, which includes vitamins $A, D_{3}, E, B_{1}, B_{2}, B_{12}$, pantothenic and ascorbic acids, niacin, biotin; non-organic compounds of microelements - sulfates of cobalt, copper, zinc, iron, manganese, potassium iodide, sodium selenite; amino acids - lysine, threonine, methionine.

Using Marmix mineral-vitamin premix on pregnant horses during 60 days causes recovery of clinical status, erythropoiesis, level of cobalt $(0.54 \pm 0.03 \mu \mathrm{mol} / \mathrm{l})$ and copper $(6,01 \pm 0,18 \mu \mathrm{mol} / \mathrm{l})$, normalizing of the calcium-phosphorus ratio, increase in the phosphorus content in the blood $(\mathrm{P}<0.001)$, vitamin $\mathrm{A}(\mathrm{P}<0.001)$ and tocopherol $(\mathrm{P}<0.001)$, total protein $(\mathrm{P}<0.001)$, decrease in the content of urea, activity of AspAT, AlAT and alkaline phosphate.

Marmix mineral-vitamin complex should be used as a homogenous mixture with fodder once a day during 60 days in morning feeding with the dose calculated at $100 \mathrm{~g}$ per mare, beginning in the 9th month of pregnancy.

\section{References}

Adamu, L., Noraniza, M. A., Rasedee, A., \& Bashir, A. (2010). Effects of race distance on physical, hematological and biochemical parameters of endurance horses. American Journal of Animal and Veterinary Sciences, 5(4), 244-248.

Anderson, M. G. (1975). The influence of exercise on serum enzyme levels in the horse. Equine Veterinary Journal, 7, 160-165.

Barrelet, A., \& Ricketts, S. (2002). Hematology and blood biochemistry in the horse: A guide to interpretation. In Practice, 6, 318-327.

Barton, M., Williamson, L., \& Jacks, S. (2003). Body weight, hematologic findings, and serum and plasma biochemical findings of horses competing in a 48-, 83-, or 159-km endurance ride under similar terrain and weather conditions. American Journal of Veterinary Research, 64, 746-753.

Bayeva, T. I., \& Zhegunov, G. F. (2016). Vplyv fizychnoho ta emotsiinoho navantazhennia na metabolichnyi profil syrovatky krovi sportyvnykh konei [Influence of physical and emotional activity on the metabolic profile of blood serum of race horses]. Visnyk of Dnipropetrovsk University. Biology, Ecology. 24(2), 484488 (in Ukrainian).

Bazzano, M., Giannetto, C., Fazio, F., \& Bazzano, M. (2014). Metabolic profile of broodmares during late pregnancy and early post-partum. Reproduction in Domestic Animals, 49, 947-953.

Clarke, A. F., Madelin, T. M., \& Allpress, R. G. (1987). The relationship of air hygiene in stables to lower airway disease and pharyngeal lymphoid hyperplasia in two groups of Thoroughbred horses. Equine Veterinary Journal, 19(6), 524-530.

Fielding, C. L., Magdesian, K. G., Rhodes, D. M., Meier, C. A., \& Higgins, J. C. (2009). Clinical and biochemical abnormalities in endurance horses eliminated from competition for medical complications and requiring emergency medical treatment: 30 cases (2005-2006). Journal of Veterinary Emergency and Critical Care, 19(5), 473-478.

Gerber, V., Tessier, C., \& Marti, E. (2014). Genetics of upper and lower airway diseases in the horse. Equine Veterinary Journal, 47(4), 390-397.

Golovach, M. J., Ganynec', P. P., \& Golovach, M. M. (2005). Vykorystannja konej gucul's'koi' porody ta i'h pomisej dlja riznyh form gipoterapii' [Use of Hucul purebred and hybrid horses for various forms of hippotherapy]. Sil's'kyj Gospodar, 7-8, 16-18 (in Ukrainian).

Gutyj, B. V., Murs'ka, S. D., Gufrij, D. F., Hariv, I. I., Levkivs'ka, N. D., Nazaruk, N. V., Gajdjuk, M. B., Pryjma, O. B., Bilyk, O. J., \& Guta, Z. A. (2016). Vplyv kadmiievoho navantazhennia na systemu antyoksydantnoho zakhystu orhanizmu buhaitsiv [Influence of cadmium loading on the state of the antioxidant system in the organism of bulls]. Visnyk of Dnipropetrovsk University. Biology, Ecology, 24(1), 96-102.

Gutyj, B., Lavryshyn, Y., Binkevych, V., Binkevych, O., Paladischuk, O., Strons'kyj, J., \& Hariv, I. (2016). Influence of Metisevit on the activity of enzyme and nonenzyme link of antioxidant protection under the bull's body cadmium loading. Scientific Messenger LNUVMBT named after S. Z. Gzhytskyj, 18(2), 52-58.

Hinchcliff, K. W., Lauderdale, M. A., Dutson, J., Geor, R. J., Lacombe, V. A., \& Taylor, L. E. (2002). High intensity exercise conditioning increases accumulated oxygen deficit of horses. Equine Veterinary Journal, 34(1), 9-16.

Hunter, D., De Lange, M., \& Snjeder, H. (2001). Genetic contribution to bone metabolism, calcium excretion and vitamin $\mathrm{D}$ and parathyroid hormone regulation. Journal of Bone and Mineral Research, 16, 371-378.

Khariv, M. I., \& Gutyj, B. V. (2016). Vplyv liposomalnoho preparatu Butaintervit na proteinsyntezuvalnu funktsiiu pechinky shchuriv za otruiennia tetrakhlormetanom [Influence of the liposomal preparation Butaintervite on protein synthesis function in the livers of rats under the influence of carbon tetrachloride poisoning]. Visnyk of Dnipropetrovsk University. Biology, Medicine, 7(2), 123-126 (in Ukrainian).

Khariv, M., Gutyj, B., Butsyak, V., \& Khariv, I. (2016). Hematolohichni pokaznyky orhanizmu shchuriv za umov oksydatsiinoho stresu ta za dii liposomalnoho preparatu [Hematological indices of rat organisms under conditions of oxidative stress and liposomal preparation action]. Biological Bulletin of Bogdan Chmelnitskiy Melitopol State Pedagogical University, 6(1), 276289 (in Ukrainian).

Kryvda, M. (2016). Analiz porushen reproduktsiinoi funktsii kobyl za latentnoho perebihu rynopnevmonii [Analysis of the disorders in reproductive function of mares with latent form of the herpesvirus type-1]. Scientific Messenger of LNU of Veterinary Medicine and Biotechnologies, 18(3), 167-170 (in Ukrainian).

Lacerda, L., Campos, R., \& Sperb, M. (2006). Hematologic and biochemical parameters in three high performance horse breeds from southern Brazil. Archives of Veterinary Science, 11, 40-44.

Lavryshyn, Y. Y., Varkholyak, I. S., Martyschuk, T. V., Guta, Z. A., Ivankiv, L. B., Paladischuk, O. R., Murska, S. D., Gutyj, B. V., \& Gufriy, D. F. (2016). Biolohichne znachennia systemy antyoksydantnoho zakhystu orhanizmu tvaryn [The biological significance of the antioxidant defense system of animals' organisms]. Scientific Messenger LNUVMBT named after S. Z. Gzhytskyj, 18(2), 100-111 (in Ukrainian). 
Lindner, A., \& Hatzipanagiotou, A. (1998). Effect of age and of performance parameters on $\mathrm{CK}, \mathrm{LDH}$ and AST activities in plasma of standardbred horses during exercise. Pferdeheilkunde, 14, 456-460.

Lindner, A., Mosen, H., Kissenbeck, S., Fuhrmann, H., \& Sallman, H. P. (2009). Effect of blood lactate-guided conditioning of horses with exercise of differing durations and intensities on heart rate and biochemical parameters. Journal of Animal Science, 87(10), 3211-3217.

Lucenko, M. V., \& Petrushko, M. P. (2015). Vplyv fizychnoho navantazhennia na dynamiku pokaznykiv krovi konei riznoho viku [Influence of physical activity on dynamics of blood indices of horses of different ages]. Odesa National University Herald. Biology, 20(1), 178-185 (in Ukrainian).

Martyshuk, T. V., Gutyj, B. V., \& Vishchur, O. I. (2016). Riven produktiv perekysnoho okysnennia lipidiv u krovi shchuriv za umov oksydatsiinoho stresu ta za dii liposomalnoho preparatu "Butaselmevit" [Level of lipid peroxidation products in the blood of rats under the influence of oxidative stress and under the action of liposomal preparation of "Butaselmevit"]. Biological Bulletin of Bogdan Chmelnitskiy Melitopol State Pedagogical University, 6(2), 22-27 (in Ukrainian).

Muñoz, A., Riber, C., Trigo, P., \& Castejón, F. (2012). Age- and genderrelated variations in hematology, clinical biochemistry, and hormones in Spanish fillies and colts. Research in Veterinary Science, 93, 943-949.

Padalino, B., Raidal, S., \& Carter, N. (2017). Immunological, clinical, haematological and oxidative responses to long distance transportation in horses. Research in Veterinary Science, 115, 78-87.

Piddubnjak, O. V., \& Golovaha, V. I. (2008). Porivnjal'na harakterystyka pokaznykiv gemopoezu u konej [Comparative characteristics of indicators of hemopoiesis in horses]. Visnyk Bilocerkivs'kogo Derzhavnogo Agrarnogo Universytetu, 56, 135-139 (in Ukrainian).

Reitman, S., \& Frankel, S. (1957). A colorimetric method for the determination of serum glutamic oxalacetic and glutamic pyruvic transaminases. American Journal of Clinical Pathology, 164(1), 321-325.

Rud'ko, G. I., \& Macijevs'ka, O. O. (2009). Doslidzhennja gidrogeohimichnyh pokaznykiv pidzemnoi' gidrosfery zahidnyh regioniv Ukrai'ny na vmist mikroelementiv [Research into hydrogeochemical indicators of the underground hydrosphere in western regions of Ukraine for content of microele- ments]. Visnyk Nacional'nogo Universytetu 'L'vivs'ka politehnika”, 655, 250-256 (in Ukrainian).

Scantlebury, C. E., Archer, D. C., Proudman, C. J., \& Pinchbeck, G. L. (2014). Management and horse-level risk factors for recurrent colic in the UK general equine practice population. Equine Veterinary Journal, 47(2), 202-206.

Shherbatyj, A. R., \& Slivins'ka, L. G. (2013). Diagnostyka mikroelementoziv kobyl u zahidnij biogeohimichnij zoni Ukrainy [Diagnosis of microelementosis of mares from the western biogeochemical zone of Ukraine]. Veterynarna Medycyna Ukrai'ny, 206, 25-28 (in Ukrainian).

Shherbatyj, A. R., Slivins'ka, L. G., \& Maksymovych I. A. (2013). Funkcional'nyj stan pechinky ta nyrok u kobyl za gipokobal'tozu i gipokuprozu [Functional condition of the liver and kidneys of mares with hypocobaltosis and hypocuprosis]. Scientific Messenger LNUVMBT named after S. Z. Gzhytskyj, 55, 257-261 (in Ukrainian).

Stefurak, J. P. (2004). Stan ta perspektyvy rozvedennja gucul's'koi' porody konej na Prykarpatti [Condition and perspectives for breeding Hucul horses in the Precarpathian region]. Naukovyj Visnyk Ukrai'ns'kogo Derzhavnogo Lisotehnichnogo Universytetu, 14(3), 456-463 (in Ukrainian).

Takasu, M., Nagatani, N., \& Tozaki, T. (2013). Hematological and biochemical reference values for the endangered Kiso horse. Journal of Equine Science, 24(4), 75-78.

Tkachev, A. V., Sheremeta, V. I., \& Tkacheva, O. L. (2016). Vplyv chasu shtuchnoho osimeninnia vidnosno ovuliatsii na zaplidniuvanist kobyl [Influence of timing of artificial insemination relative to ovulation on conception in mares]. Scientific Messenger LNUVMBT named after S.Z. Gzhytskyj, 18(2), 241-244.

Vysochans'ka, L. J. (2010). Osoblyvosti ta ekonomichna efektyvnist' vykorystannja konej u gospodarstvah usih form vlasnosti Ivano-Frankivshhyny [Peculiarities and economic effectiveness of using horses on farms under all types of ownership in Ivano-Frankovsk region]. Innovacijna Ekonomika, 5, 48-50 (in Ukrainian).

Wingfield, N. J. (1984). Horse ailments and health care: A practical horse guide Colin Vogel. Equine Veterinary Journal, 16(1), 52.

Wood, D. R. (2004). Veterinary laboratory medicine, interpretation and diagnosis, 3rd edition. Veterinary Clinical Pathology, 33(3), 182-182. 